\title{
INTERACTIONS BETWEEN SURFACE CONDITIONS, THE MEDITERRANEAN SEA, AND CAVE CLIMATE WITHIN TWO LITTORAL CAVES IN MALLORCA: IMPLICATIONS FOR THE FORMATION OF PHREATIC OVERGROWTHS ON SPELEOTHEMS
}

\author{
Liana M. Boop ${ }^{1 *}$, Jonathan G. Wynn ${ }^{2}$, Glenn Thompson ${ }^{2}$, Joan J. Fornós ${ }^{3}$, and Bogdan P. Onac ${ }^{2}$
}

\begin{abstract}
Phreatic overgrowths on speleothems from Mallorca's littoral caves are valuable markers of former sea-level stands. These carbonate encrustations form as $\mathrm{CO}_{2}$ degasses from brackish cave water that is hydrologically connected to the Mediterranean Sea. This study uses time series analysis to document relationships between surface conditions of temperature, barometric pressure, precipitation, tidal level of the Mediterranean Sea, and the coastal caves' microenvironment of temperature, partial pressure of $\mathrm{CO}_{2}\left(p \mathrm{CO}_{2}\right)$, and water level to contextualize overgrowth formation in Cova des Pas de Vallgornera (Vallgornera) and Coves del Drac (Drac). Water level in both caves was an attenuated semidiurnal function of Mediterranean Sea level with a lag of about four hours. The impact of individual rainfall events on cave water level was negligible during the study period. $p \mathrm{CO}_{2}$ of cave air at both sites reached an annual maximum in September and decreased rapidly when surface air temperature fell below the cave air temperature (mean $\sim 19^{\circ} \mathrm{C}$ ). As this threshold was reached, cooler and denser tropospheric air descended into the caves, initiating cave ventilation and displacing high- $p \mathrm{CO}_{2}$ cave air that had accumulated. Observed $p \mathrm{CO}_{2}$ was lower in Drac than in Vallgornera, and had small daily fluctuations because of bigger passages, fewer constrictions, and a large collapse entrance. The frequency and magnitude of $p \mathrm{CO}_{2}$ fluctuations were higher in Vallgornera than in Drac, with both caves showing twicedaily water level maxima causing displacement of high- $p \mathrm{CO}_{2}$ air from the cave alternating with water level minima causing tropospheric air to enter the cave via a "piston effect." A secondary control on $p \mathrm{CO}_{2}$ variation can be attributed to variation in tropospheric barometric pressure. Thus, the geochemical conditions favorable for overgrowth formation are, in part, the result of this tidally-controlled cycle of cave-water level. The cycle causes cavetroposphere air exchange that drives $\mathrm{CO}_{2}$ degassing, and therefore, the formation of phreatic overgrowths on speleothems.
\end{abstract}

\section{INTRODUCTION}

Mallorca's diverse Quaternary geomorphological features have made the island a world-renowned location for Quaternary sea level research (Ginés et al., 2012a). Coastal features including wave cut notches, marine terraces, fossil assemblages, and beach deposits document former sea level stands (Butzer, 1962; Butzer \& Cuerda, 1962, Goy \& Zazo, 1986; Hearty et al., 1986; Hearty, 1987; González-Hernández et al., 2001). The littoral caves of Mallorca host carbonate encrustations known as phreatic overgrowths on speleothems (POS) that have been used to refine the western Mediterranean Sea eustatic curve (Vesica et al., 2000; Tuccimei et al., 2006; Dorale et al., 2010; Ginés et al., 2012b). POS are robust sea level proxies because they provide precise geographic location, elevation, age, and tidal range (Ginés \& Ginés, 1972; Pomar et al., 1979; Ginés \& Ginés, 2007; van Hengstum et al., 2015). POS form when $\mathrm{CO}_{2}$ degasses at the air-water interface (Pomar et al., 1976, 1979; Csoma et al., 2006; Boop et al., 2014); they are widespread in Mallorca, with over 30 identified POS paleolevels from $46 \mathrm{~m}$ above to $23 \mathrm{~m}$ below current sea level (Ginés, 2000). Some of the POS observed above the water table have been correlated with fossil marine terraces and beach deposits (Cuerda, 1975; Pomar and Cuerda, 1979). POS precipitated by former sea level stands are generally left intact within the stable cave environment, whereas beach deposits may be reworked and terraces or wave cut notches may be removed or overprinted by subsequent transgressions. In addition, encrustations that correspond to former sea level lowstands are preserved and accessible,

\footnotetext{
* Corresponding Author: liana.boop@sjcd.edu

${ }^{1}$ Department of Natural Sciences, San Jacinto College, 5800 Uvalde Rd., Houston, TX 77049, USA

${ }^{2}$ School of Geosciences, University of South Florida, 4202 E. Fowler Ave., NES 107, Tampa, FL 33620, USA

${ }^{3}$ Earth Sciences (Geology and Paleontology "Guillem Colom") Research Group, Department of Biology, Universitat de les Illes Balears, Cra. Valldemossa, km 7.5, 07122, Palma de Mallorca, Spain
} 
Interactions between surface conditions, the Mediterranean Sea, and cave climate within two littoral caves in Mallorca: IMPLICATIONS FOR THE FORMATION OF PHREATIC OVERGROWTHS ON SPELEOTHEMS

whereas surface geomorphological evidence of lowstands is often inaccessible or destroyed by surficial processes.

Studies on the mechanisms of POS formation have focused on their distribution and mineralogy (Pomar et al., 1979; Csoma et al., 2006; Ginés et al., 2012a). However, the interactions of the subterranean environment with external forcings, including surface air temperature, precipitation, barometric pressure, tide, and sea level have not been quantified in high temporal resolution. This study uses time series analysis on data collected in-situ to investigate the effect that external forcings have on the subsurface air and water temperatures, partial pressure of $\mathrm{CO}_{2}\left(p \mathrm{CO}_{2}\right)$, and cave water level to address the following research questions: what are the effects of rainfall and tidal fluctuations on cave water level and to what extent is cave air $\mathrm{CO}_{2}$ controlled by atmospheric forcings like barometric pressure, temperature, or tidal pumping?

\section{Methods}

\section{Site Characteristics}

The island of Mallorca is located in the western Mediterranean and is the largest of the Balearic Islands. The geological structure of Mallorca consists of a set of northeastsouthwest trending horsts and grabens formed during the middle-upper Miocene. Horsts correspond to the mountain ranges structured as a thrust and fold belt during the Alpine Orogeny, the Tramuntana range to the west and the gentler Llevant ranges in the east, and the grabens correspond to the basins, Es Pla and Migjorn among others, where horizontal upper Miocene carbonate platforms crop out (Fornós et al., 2002; Sàbat et al., 2011). This extensional event responsible for Mallorca's present day topography occurred mainly in the upper Miocene; since this event, Mallorca has remained relatively stable in terms of vertical movements (Just et al., 2011).

The climate of Mallorca is typical of the Mediterranean, with hot, dry summers and mild winters. Mean annual temperature is $16.6{ }^{\circ} \mathrm{C}$ (Guijarro, 1995), and yearly rainfall totals are highly variable, ranging from $300 \mathrm{~mm}$ in the central and south-eastern part to $1400 \mathrm{~mm}$ along the Tramuntana range (Ginés et al., $2012 \mathrm{~b}$ ). The coastal areas of Mallorca are considered lowenergy environments characterized by semidiurnal microtides $(<25 \mathrm{~cm})$. Tidal range, however, varies seasonally due to wind stress and changes in barometric pressure, but remains between 0 and $23 \mathrm{~cm}$ (García et al., 2000).

Two caves were selected for this study, both hosting modern phreatic overgrowths on speleothems at the present water table: Cova des Pas de Vallgornera (Vallgornera), located on Mallorca's southern coast near Cala Pi in the Llucmajor municipality, and Coves del Drac, on the eastern coast in the outskirts of Porto Cristo (Fig. 1). The two littoral caves are each within a horizontal distance of about $400 \mathrm{~m}$ of the coast and developed in upper Miocene calcarenites and limestones at less than $25 \mathrm{~m}$ below the surface (Ginés \&
Ginés, 2007; Ginés et al., 2014). Vallgornera has $74 \mathrm{~km}$ of mapped passage that is accessed by a single nearly-sealed entrance (Merino et al., 2014). With less than $4 \mathrm{~km}$ of passages (Gràcia et al., 2007), Drac is the most visited cave in Europe (Robledo \& Durán, 2010). Since about 3000 tourists a day spend about an hour covering $1.2 \mathrm{~km}$ of the cave, their respiration likely increases the cave atmosphere $p \mathrm{CO}_{2}$. To maintain the natural conditions of temperature, relative humidity, and $\mathrm{CO}_{2}$ concentration, the cave is artificially ventilated, further altering the natural conditions. The study area is in the non-touristic part of the cave. Therefore, any impacts of present day tourism, including altered temperature, relative humidity, and $p \mathrm{CO}_{2}$, are minimal at the monitoring site. However, samples collected by Boop (2014) and JJF suggest that higher $p \mathrm{CO}_{2}$ is present in non-tourist areas of the cave, likely due to the decomposition of bat guano, passage morphology, and less efficient natural ventilation in this section of the cave.

\section{Data Collection}

This study was designed to monitor the physical and chemical conditions at the air-water interface where overgrowths precipitate. Sensors were installed in both caves for almost 16 months between December 2011 and March 2013. Sample intervals varied by parameter based on the needs of resolution, sensor memory, and the field schedule. Sensor malfunctions resulted in incomplete records.

A YSI 6920 sonde was fitted into a foam float and tethered to monitor conditions at $15 \mathrm{~cm}$ of depth within the water column at a fixed location. Cave-water temperature $\left(\mathrm{T}_{\mathrm{w}}\right)$ (accuracy $\pm 0.15{ }^{\circ} \mathrm{C}$; precision $0.01{ }^{\circ} \mathrm{C}$ ) was measured at $3 \mathrm{hr}$ intervals. Cave-water level $\left(\mathrm{WL}_{\mathrm{c}}\right)$ was calculated at $15 \mathrm{~min}$ intervals using In-Situ Baro Merge software with water pressure from an In-Situ Aqua TROLL (accuracy \pm 1.05 $\mathrm{hPa}$; precision $0.5 \mathrm{hPa}$ ), and barometric pressure (p) (accuracy $\pm 1.5 \mathrm{hPa}$; precision $0.075 \mathrm{hPa}$ ) from an In-Situ Baro TROLL sensor, which also collected cave air temperature $\left(\mathrm{T}_{\mathrm{c}}\right)$ (accuracy $\pm 0.1{ }^{\circ} \mathrm{C}$; precision $0.01{ }^{\circ} \mathrm{C}$ ). The accuracy of the barometric-pressure-based water level is $\pm 0.021 \mathrm{~m}$. The mean was subtracted from $\mathrm{WL}_{\mathrm{c}}$ to compare relative water level fluctuations. The Aqua TROLL sensors in both caves failed 11 months after their deployment.

A CO2meter.com K33-ELG logger (accuracy $\pm 30 \mathrm{ppm}$; precision $20 \mathrm{ppm}$ ) recorded hourly $\mathrm{CO}_{2}$. The $\mathrm{CO}_{2}$ readings were converted to partial pressure $\left(p \mathrm{CO}_{2}\right)$ using the relationship $p \mathrm{CO}_{2}=\mathrm{CO}_{2 \text { (raw) }} \times 1013 / \mathrm{p}$, where $\mathrm{CO}_{2}$ (raw) is the input data and $\mathrm{p}$ is in-cave barometric pressure (Spötl et al., 2005).

Additional data were obtained from governmental organizations to contextualize the cave specific data. Surface temperature $\left(\mathrm{T}_{\mathrm{s}}\right)\left({ }^{\circ} \mathrm{C} ; 3 \mathrm{hr}\right.$ intervals) and precipitation $(\mathrm{P})$ (mm; daily totals) from the Agencia Estatal de Meteorología (AEMet) weather stations Llucmajor II (Llucmajor) and Manacor-Poliesportiu (Manacor) were the closest available to Vallgornera and Drac, respectively. To determine maxima, minima, and lags during 2012, the daily averages of cave air 


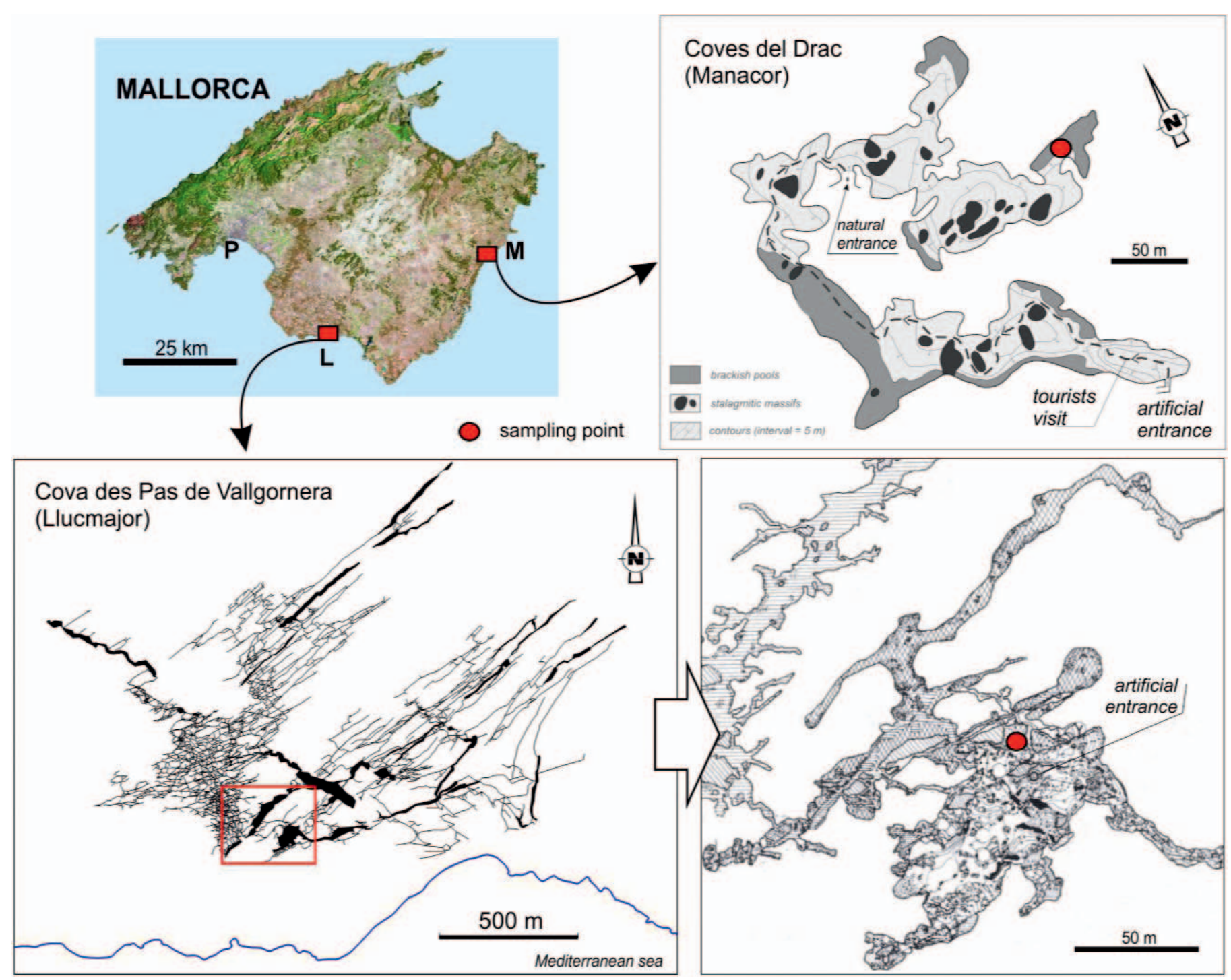

Figure 1. Map of Mallorca and caves studied. Palma Sea Level Monitoring Facility is indicated by P; Llucmajor II AEMet and the Manacor weather stations are indicated with $L$ and $M$, respectively. The map of Drac is modified after Ginés and Ginés (2007) and those of Vallgornera are modified from Merino et al. (1993, 2014).

Table 1. Maxima, minima, and averages for temperature $(T)$ and $p \mathrm{CO}_{2}$ during 2012. The average surface temperature $\left(\mathrm{T}_{\mathrm{s}}\right)$, cave air temperature $\left(\mathrm{T}_{\mathrm{c}}\right)$, cave water temperature $\left(\mathrm{T}_{\mathrm{w}}\right)$, and $p \mathrm{CO}_{2}$ were computed for each day. This daily data was smoothed using a 7 day moving-average filter. $p \mathrm{CO}_{2}$ averages were excluded due to missing data.

\begin{tabular}{|c|c|c|c|c|c|c|c|c|}
\hline \multirow[b]{2}{*}{ Parameter } & \multicolumn{4}{|c|}{ Vallgornera } & \multicolumn{4}{|c|}{ Drac } \\
\hline & $\mathrm{T}_{\mathrm{w}},{ }^{\circ} \mathrm{C}$ & $\mathrm{T}_{\mathrm{c}},{ }^{\circ} \mathrm{C}$ & $\mathrm{T}_{\mathrm{s}},{ }^{\circ} \mathrm{C}$ & $p \mathrm{CO}_{2}, \mathrm{ppm}$ & $\mathrm{T}_{\mathrm{w}},{ }^{\circ} \mathrm{C}$ & $\mathrm{T}_{\mathrm{c}},{ }^{\circ} \mathrm{C}$ & $\mathrm{T}_{\mathrm{s}},{ }^{\circ} \mathrm{C}$ & $p \mathrm{CO}_{2}, \mathrm{ppm}$ \\
\hline \multirow[t]{2}{*}{2012 Maximum } & 19.69 & 19.44 & 27.82 & 2,328 & 18.51 & 18.43 & 26.86 & 1,072 \\
\hline & $9 / 12 / 12$ & $10 / 19 / 12$ & $8 / 11 / 12$ & $9 / 23 / 12$ & $11 / 19 / 13$ & $12 / 24 / 12$ & $8 / 11 / 12$ & $8 / 28 / 12$ \\
\hline \multirow[t]{2}{*}{2012 Minimum } & 19.23 & 18.99 & 6.05 & 1,007 & 18.45 & 18.31 & 6.34 & 399 \\
\hline & $4 / 17 / 12$ & $4 / 15 / 12$ & $2 / 8 / 12$ & $12 / 18 / 12$ & $5 / 22 / 12$ & $5 / 7 / 12$ & $2 / 7 / 12$ & $1 / 6 / 12$ \\
\hline Study Average & 19.4 & 19.2 & 15.6 & $\ldots$ & 18.5 & 18.4 & 15.5 & $\ldots$ \\
\hline
\end{tabular}


Interactions between surface conditions, the Mediterranean Sea, and cave climate within two littoral caves in Mallorca: IMPLICATIONS FOR THE FORMATION OF PHREATIC OVERGROWTHS ON SPELEOTHEMS

and cave water temperatures, surface temperatures, and $p \mathrm{CO}_{2}$ were computed, and then smoothed with a 7 day moving average filter. Finally, absolute tide gauge level $\left(\mathrm{WL}_{\mathrm{P}}\right)$ from the Palma de Mallorca UNESCO-IOC Sea Level Station Monitoring Facility (2016) was downloaded in 15-min intervals that corresponded with the measurements of the cave-water level.

\section{Time Series Analysis}

Time series analysis was used to evaluate temporal trends in data collected at regular intervals. Analyses presented below were computed using commands in the Signal Processing Toolbox of Matlab 2013a. Frequency-domain figures are terminated below the Nyquist frequency, equal to half of the sampling frequency.

The relationship between tide gauge and cave water levels at each cave was investigated using coherency analysis. To examine controls on cave $p \mathrm{CO}_{2}$, coherency analysis was also used to investigate barometric pressure, cave and surface temperatures, and water level in the caves. Coherency is a function of the power-spectral densities of each time series, and their cross-power spectral density. Coherency measures how well correlated two time series are as a function of frequency, with values between 0 (incoherent) and 1 (perfectly coherent). It also measures the phase angle, $\psi$, between these time series as a function of frequency. Thus if there is a strong coherency at a particular frequency, both time series must have significant energy at that frequency, and from $\psi$ the time lag in hours can be determined. Magnitude-squared coherency estimates were computed using the MSCOHERE Matlab command, using a Hamming window of length 256 samples with an overlap of 128 samples.

Spectrograms are computed to investigate the temporal behavior of periodic signals. To identify high-frequency $p \mathrm{CO}_{2}$ fluctuations, a stationary time series was created: the annual signal was removed by subtracting a 20-point (20-hr) moving average. Spectrograms were computed using the SPECTROGRAM Matlab command, a window length of 24 samples, an overlap of 12 samples, and a 2048-sample fast Fourier transform.

\section{RESUlts}

\section{Meteorological Data}

Surface temperature and precipitation show similar patterns at both sites (Fig. 2). During the study period, mean $\mathrm{T}_{\mathrm{s}}$ was $15.6{ }^{\circ} \mathrm{C}$ at Llucmajor and $15.5^{\circ} \mathrm{C}$ at Manacor. Relative to $\mathrm{T}_{\mathrm{s}}$, which displays annual and daily fluctuations, cave air temperatures were nearly stable within $0.5{ }^{\circ} \mathrm{C}$ (Figs. 2A2C). Total precipitation $\mathrm{P}$ differed between sites, with 485.4 $\mathrm{mm}$ recorded at Llucmajor (Fig. 2A) and $392.2 \mathrm{~mm}$ at Manacor (Fig. 2B).

\section{Cave Air and Water Temperature}

Over the study period, mean water temperature in Vallgornera was $19.4^{\circ} \mathrm{C}$, whereas mean cave air temperature was $19.2^{\circ} \mathrm{C}$ (Table 1$)$, and $\mathrm{T}_{\mathrm{w}}$ was always greater than $\mathrm{T}_{\mathrm{c}}($ Fig. 2C). During 2012, maximum $\mathrm{T}_{\mathrm{c}}$ lagged that of $\mathrm{T}_{\mathrm{w}}$ by 37 days (Table 1). In contrast, minimum $\mathrm{T}_{\mathrm{c}}$ lagged that of $\mathrm{T}_{\mathrm{w}}$ by two days.

During the study, mean $\mathrm{T}_{\mathrm{c}}$ and $\mathrm{T}_{\mathrm{w}}$ in Drac were 18.4 and $18.5^{\circ} \mathrm{C}$, respectively, with ranges of only 0.2 and $0.15{ }^{\circ} \mathrm{C}$, respectively (Table 1). These values are similar to spot measurements recorded in the touristic part of the cave by BPO, where temperatures would rise well above $21{ }^{\circ} \mathrm{C}$ when large groups (about 500 people) visited the cave and when forced-air ventilation was not in operation.

As in Vallgornera, $T_{w}$ in Drac was always greater than $T_{c}$ (Fig. 2C). The range of $\mathrm{T}_{\mathrm{w}}$ was lower in Drac, making it difficult to determine maxima and minima and determine lag times. During 2012, the maximum $T_{c}$ in Drac lagged $T_{s}$ by 135 days; the same lag in Vallgornera was only 69 days (Fig. 2; Table 1). Maximum $\mathrm{T}_{\mathrm{w}}$ in Vallgornera followed maximum $\mathrm{T}_{\mathrm{s}}$ after 32 days. Minimum $\mathrm{T}_{\mathrm{c}}$ and $\mathrm{T}_{\mathrm{w}}$ in Vallgornera lag $\mathrm{T}_{\mathrm{s}}$ by 67 and 69 days, respectively. Minimum $T_{c}$ and $T_{w}$ in Drac were recorded 90 and 105 days after minimum $\mathrm{T}_{\mathrm{s}}$, respectively.

\section{CAve $P \mathrm{CO}_{2}$}

In both caves, peak $p \mathrm{CO}_{2}$ occurred in August/September (Table 1, Fig. 2D). $p \mathrm{CO}_{2}$ in Vallgornera was higher than in Drac and showed greater amplitude of variation on annual and daily scales. The time between the highest and lowest recorded $p \mathrm{CO}_{2}$ values was 157 days in Vallgornera, and only 121 days in Drac.

There is significant surface temperature $\mathrm{T}_{\mathrm{s}}-p \mathrm{CO}_{2}$ coherency in Vallgornera (Table 2) at a $12 \mathrm{hr}$ period. The lag time of the January - April 2012 data was $4 \mathrm{hr}$, while that of the May 2012 - March 2013 was $4.8 \mathrm{hr}$. An $8 \mathrm{hr}$ period is also present in the Vallgornera data; the lag is $3.9 \mathrm{hr}$ in the January - April 2012 data and 3.2 hr in the May 2012 - March 2013 series. No notable $\mathrm{T}_{\mathrm{s}}-p \mathrm{CO}_{2}$ relationship is observed in Drac (Table 2).

The cave water levels in Vallgornera and Drac are shown in Fig. $3 \mathrm{~A}$. $\mathrm{WL}_{\mathrm{c}}-p \mathrm{CO}_{2}$ coherency is present in Vallgornera at the 11.6hr period (Fig. 4A, Table 2). Lead times are $4.4 \mathrm{hr}$ for the January - April 2012 time series, and $2.7 \mathrm{hr}$ for the July November 2012 data (Fig. 4B). $\mathrm{WL}_{\mathrm{c}}-p \mathrm{CO}_{2}$ coherency is also present at a $12.8 \mathrm{hr}$ period with a $5 \mathrm{hr}$ lead in the January April 2012 data from Drac (Fig. 4C and D), but no cycles were identified in the July - November 2012 dataset.

Barometric pressure $\mathrm{p}-\mathrm{p} \mathrm{CO}_{2}$ coherency is present at a 12.2hr period in Vallgornera, with lead times of $5.3 \mathrm{hr}$ in the January - April 2012 data and $4.5 \mathrm{hr}$ in the July - November 2012 dataset (Table 2). Drac $\mathrm{p}-p \mathrm{CO}_{2}$ coherency analysis identified an identical $12.2 \mathrm{hr}$ period in the July - December 2012 series and a $12.8 \mathrm{hr}$ period in the January - March 2013 data. The corresponding lead times are $9 \mathrm{~min}$ and $5.5 \mathrm{hr}$, respectively. A similar $\mathrm{p}-p \mathrm{CO}_{2}$ coherency peak is not present in the January - April 2012 data from Drac. 


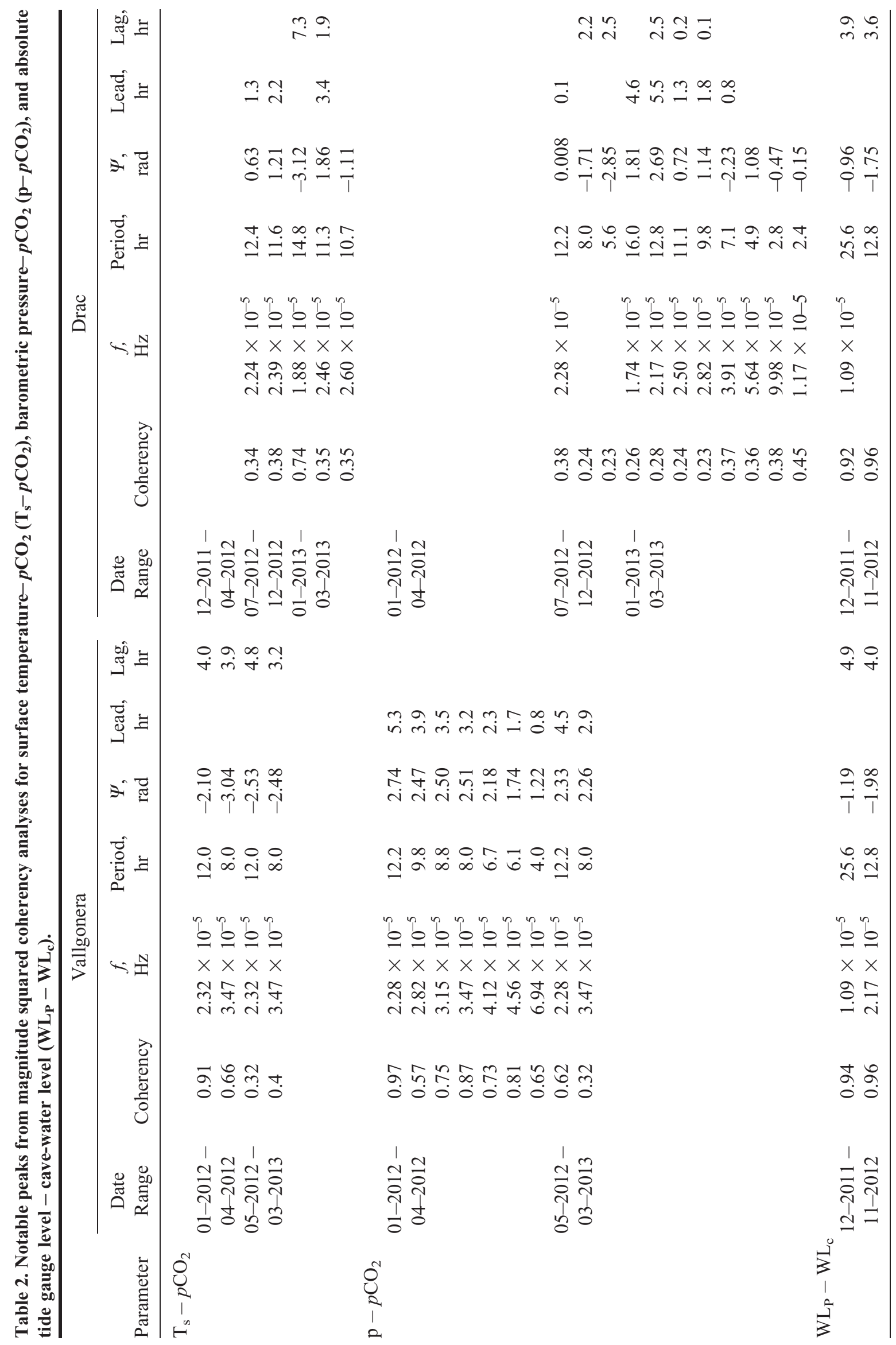


Interactions between surface conditions, the Mediterranean Sea, and Cave Climate within two littoral caves in Mallorca: IMPLICATIONS FOR THE FORMATION OF PHREATIC OVERGROWTHS ON SPELEOTHEMS
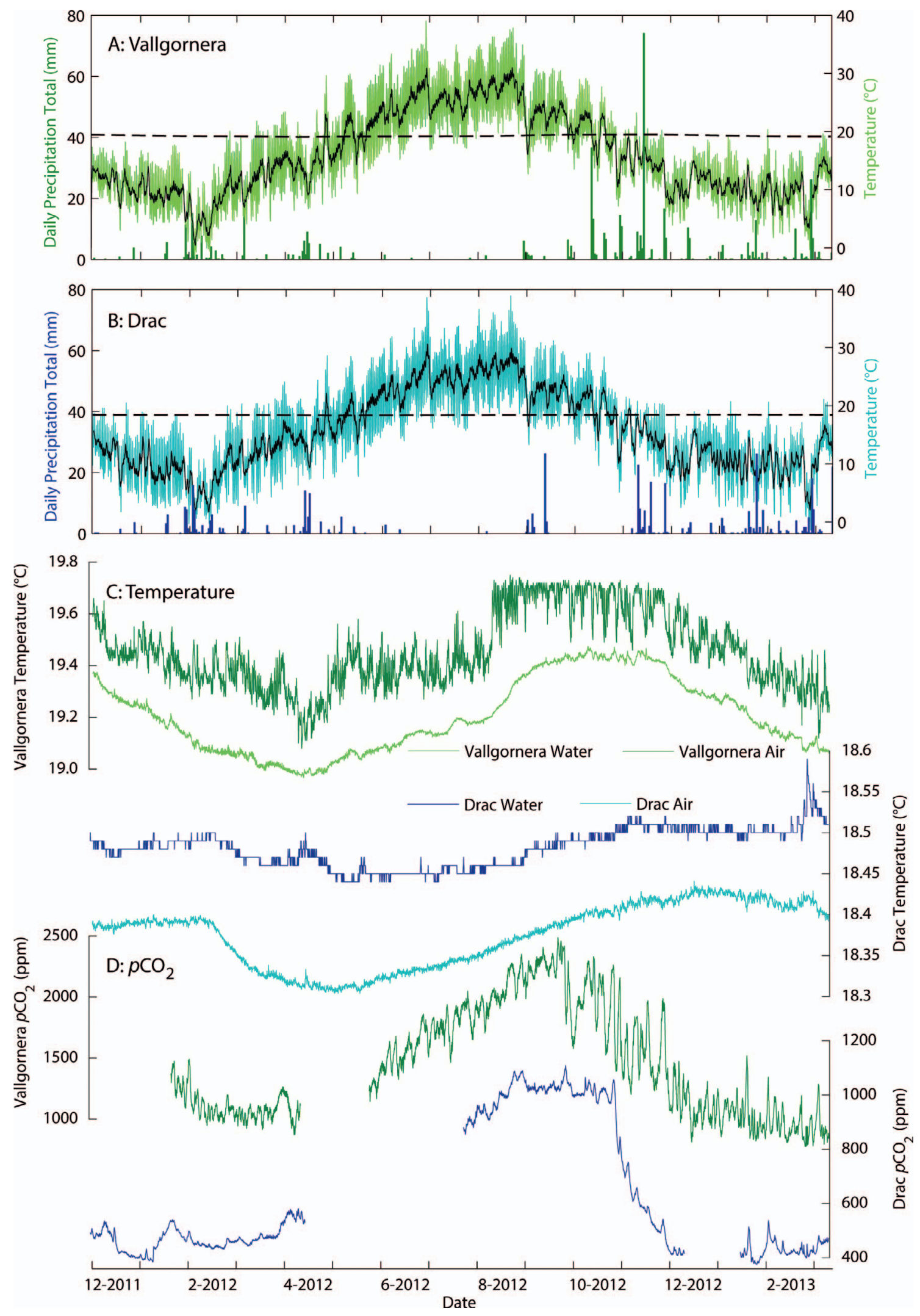

Figure 2. A) Surface temperature $\left(T_{s}\right)$ and daily precipitation (P) from AEMet Llucmajor II and B) Manacor stations. Right axis: $T_{s}$ (black line shows a 10-point moving average). Black dashed lines show cave air temperature $\left(T_{c}\right)$ for Vallgornera (A) and Drac (B) from part C. C) Detailed cave air temperature $\left(T_{c}\right)$ and water temperature $\left(T_{w}\right)$ and $\left.D\right)$ cave $\mathrm{pCO}_{2}$ (corrected for cave barometric pressure) from Vallgornera and Drac.

$64 \cdot$ Journal of Cave and Karst Studies, April 2017 

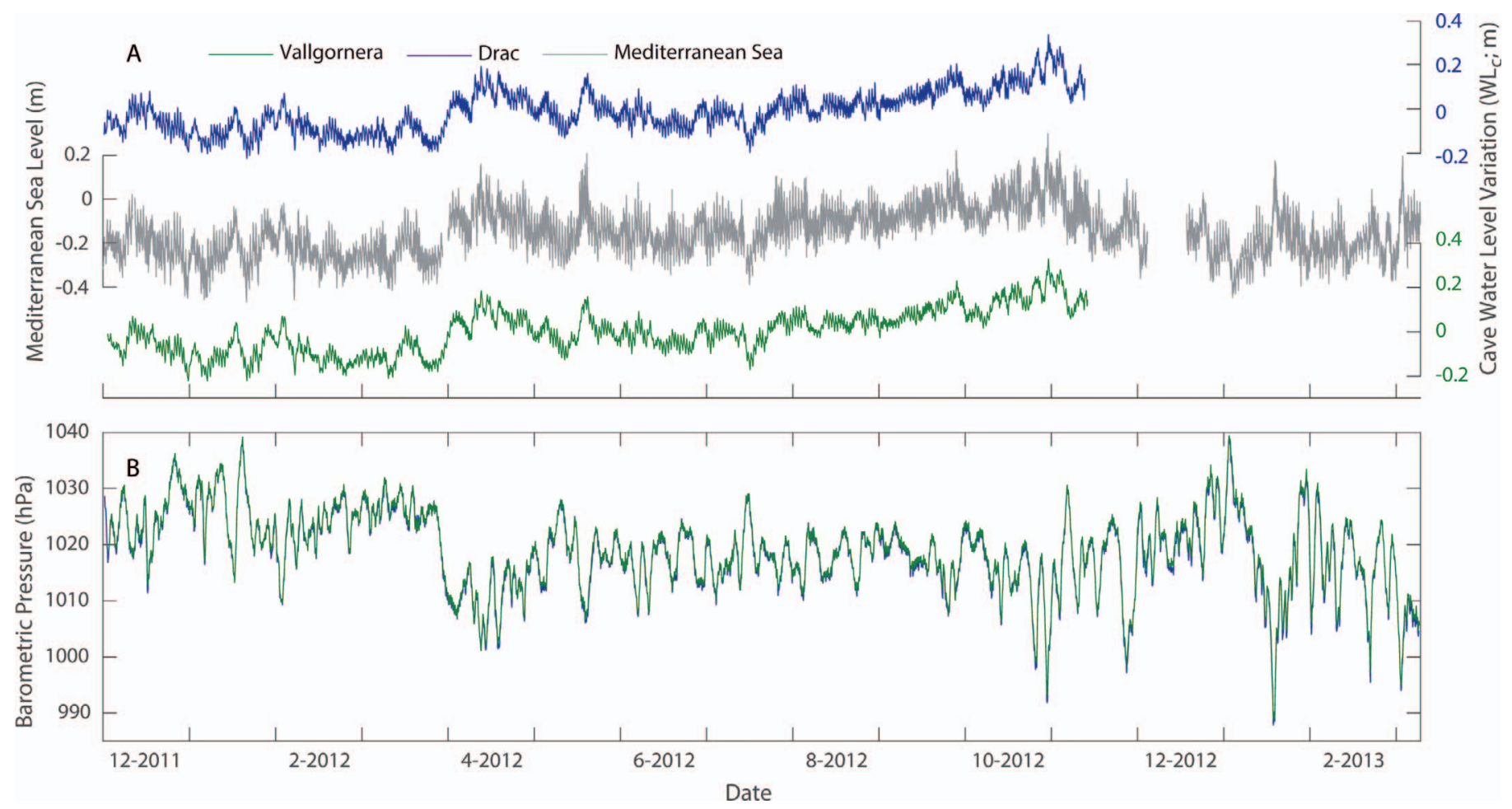

Figure 3. A) Cave water levels $\left(W L_{c}\right)$ and Mediterranean Sea Level from tide gauge $\left(W_{L_{p}}\right)$. B) Barometric pressure (p).

$p \mathrm{CO}_{2}$ records are reproduced next to the spectrograms of filtered data for both Vallgornera and Drac in Fig. 5. Highfrequency $p \mathrm{CO}_{2}$ fluctuations in Vallgornera (Fig. 5A) create spectral power at the 12-hr period in Vallgornera (Fig. 5B). In Drac, which has lower-amplitude $p \mathrm{CO}_{2}$ fluctuations (Fig. 5C), lower spectral power exists at the $12 \mathrm{hr}$ cycle at some points throughout the year (Fig. 5D).

\section{Cave Water Level}

The cave water level $\mathrm{WL}_{\mathrm{c}}$ is similar in both caves (Fig. $3 \mathrm{~A}$ ), and both records show a similarity to the tide gauge water level $\mathrm{WL}_{\mathrm{P}}$. The strongest $\mathrm{WL}_{\mathrm{P}}-\mathrm{WL}_{\mathrm{c}}$ coherency peak $(>0.96)$ in both caves corresponds to a $12.8-\mathrm{hr}$ period, and the second strongest peak $(>0.92)$ occurs at a $25.6 \mathrm{hr}$ period (Fig. 6, Table 2). In Vallgornera, the 12.8 -hr $\mathrm{WL}_{\mathrm{c}}$ cycle lags $\mathrm{WL}_{\mathrm{P}}$ by $4.0 \mathrm{hr}$, whereas the $25.8 \mathrm{-hr}$ cycle lags by $4.9 \mathrm{hr}$. The corresponding lag in Drac of the 12.8-hr cycle was $3.6 \mathrm{hr}$, while that of the $25.6-\mathrm{hr}$ cycle was $3.9 \mathrm{hr}$.

The results from the coherency analyses indicate a period close to, but not matching the lunar day $(24.8 \mathrm{hr})$. However, strong similarity between the cave $\left(\mathrm{WL}_{\mathrm{c}}\right)$ and tide gauge $\left(\mathrm{WL}_{\mathrm{P}}\right)$ water levels is clearly seen when the data are considered in the time domain (Fig. 7). Data from July $20-$ 23, 2012 was chosen because no rainfall was recorded for $>$ 30 days before this interval. The discrepancy between results in the frequency and time domains is a consequence of the 3hr sample interval of the coherency analyses; the 24.8-hr lunar day signal rounds up to the closest possible frequency output (25.6 hr). The same discrepancy applies to the mixed semi- diurnal 12.4-hr cycle that is output as strong coherency at 12.8 hr.

Over the entire study period, there was strong positive linear correlation between $\mathrm{WL}_{\mathrm{P}}$ and $\mathrm{WL}_{\mathrm{c}}$ in both caves. In Vallgornera, the $r$-value from Pearson's correlation coefficient for $\mathrm{WL}_{\mathrm{P}}$ and $\mathrm{WL}_{\mathrm{c}}$ was 0.88 (slope $y=0.82 x+1.41, n=$ 32,372 ), while that of Drac was 0.87 (slope $y=0.76 x+1.71, n$ $=32,419)$. $\mathrm{WL}_{\mathrm{P}}$ ranges $0.76 \mathrm{~m}$, whereas the ranges in $\mathrm{WL}_{\mathrm{c}}$ at Vallgornera and Drac are almost identical, 0.55 and $0.56 \mathrm{~m}$, respectively (Fig. 3A). Thus, over the study period, the attenuation of $\mathrm{WL}_{\mathrm{P}}$ is approximately $0.2 \mathrm{~m}$ at both sites.

\section{Discussion}

\section{Cave Air and Water Temperatures}

While it is generally accepted that cave temperature is a good approximation of the annual average surface temperature in the cave area (Wigley \& Brown, 1976), over the study period, mean cave $T_{c}$ and cave water $T_{w}$ temperatures in both caves are approximately $3{ }^{\circ} \mathrm{C}$ greater than mean surface temperature during the same time interval. This observation could be explained by either differences in cave ventilation regimes or the heat exchange between seawater and cave atmosphere due to each cave's hydrologic connection to the Mediterranean Sea. The higher $T_{c}$ and $T_{w}$ in Vallgornera compared to Drac may be due to the cave's proximity to a region known to host a deep thermal reservoir (López-García \& Mateos-Ruíz, 2006). Merino et al. (2011) report tempera- 
Interactions between surface conditions, the Mediterranean Sea, and Cave climate within two littoral caves in Mallorca: IMPLICATIONS FOR THE FORMATION OF PHREATIC OVERGROWTHS ON SPELEOTHEMS

tures of $27.1^{\circ} \mathrm{C}$ and $23.6{ }^{\circ} \mathrm{C}$ in Cova de sa Guitarreta and Pou de Can Carro, located less than $10 \mathrm{~km}$ northwest of Vallgornera. Based on the presence of various hypogene features and unusual mineral assemblages, thermal basal recharge may have played a major role in the speleogenesis of Vallgornera (Ginés et al., 2009, 2014; Fornós et al., 2011; Onac et al., 2014).

\section{${ }_{P} \mathrm{CO}_{2}$}

Higher $p \mathrm{CO}_{2}$ in Vallgornera compared to Drac may be attributed to limited ventilation in the former cave, which has a single closed entrance. A large, natural collapse entrance in Drac, as well as less-restricted cave passages, likely allows for stronger ventilation, maintaining lower $p \mathrm{CO}_{2}$ in cave air (Ek \& Gewelt, 1985; Hu et al., 2008).

In both caves, $p \mathrm{CO}_{2}$ increases in the summer months, with the highest concentration observed at the end of the growing season. Similar findings are reported in Banner et al. (2007), Liñán et al. (2008), Faimon et al. (2012), Cowan et al. (2013), Mandić et al. (2013), and Lang et al. (2016). The $p \mathrm{CO}_{2}$ plateau noticed in Drac between August and early November is due to this cave's particular air circulation. Annual ventilation is driven by the disparity between surface and cave temperatures during winter, when cool, relatively dense air descends into cave passages, forcing the $\mathrm{CO}_{2}$-rich air out of the cave. Throughout the summer months, the outside temperatures exceed those inside the cave causing the ventilation to slow down or cease, allowing $\mathrm{CO}_{2}$ to build up. Dumitru et al. (2015) confirmed this bi-directional ventilation regime in Drac by deploying radon sensors throughout the non-touristic branch of the cave, including one detector at the same site investigated in this study (Fig. 1). In Vallgornera and Drac, this exchange is sufficiently slow that rapid, high-amplitude decreases of $\mathrm{T}_{\mathrm{c}}$ do not coincide with the seasonal decrease of $\mathrm{pCO}_{2}$ (Fig. 2). Instead, the thermal signal is buffered between the entrances and the study sites. It is likely that the network of fractures in the overlying bedrock at Vallgornera plays a major role in the seasonal overturn, whereas in Drac, this ventilation occurs through the cave's large natural entrance.

The calculated surface temperature $\mathrm{T}_{\mathrm{s}}-p \mathrm{CO}_{2}$ coherency values and corresponding lag times suggest the possibility of overnight thermal- and density-driven ventilation in Vallgornera, but there is no peak in spectral coherency at a $24 \mathrm{hr}$ period (Table 2). Additionally, during the summer months when $T_{s}$ consistently exceeds cave temperature $T_{c}$, thermal cave gradients could not drive ventilation and high-frequency $p \mathrm{CO}_{2}$ variations.

$p \mathrm{CO}_{2}$ can be controlled by cave-barometric pressure $\mathrm{p}$ in some caves. For example, Baldini et al. (2006) report nightly ventilation due to $\mathrm{p}$ minima. Cowan et al. (2013) present diurnal fluctuations that correspond to $\mathrm{p}$ as global atmospheric tide in caves in Texas, USA. Similarly, Benavente et al. (2011) suggest that $\mathrm{p}$ may drive cave-air circulation during summer, but state that their data are insufficient to support the
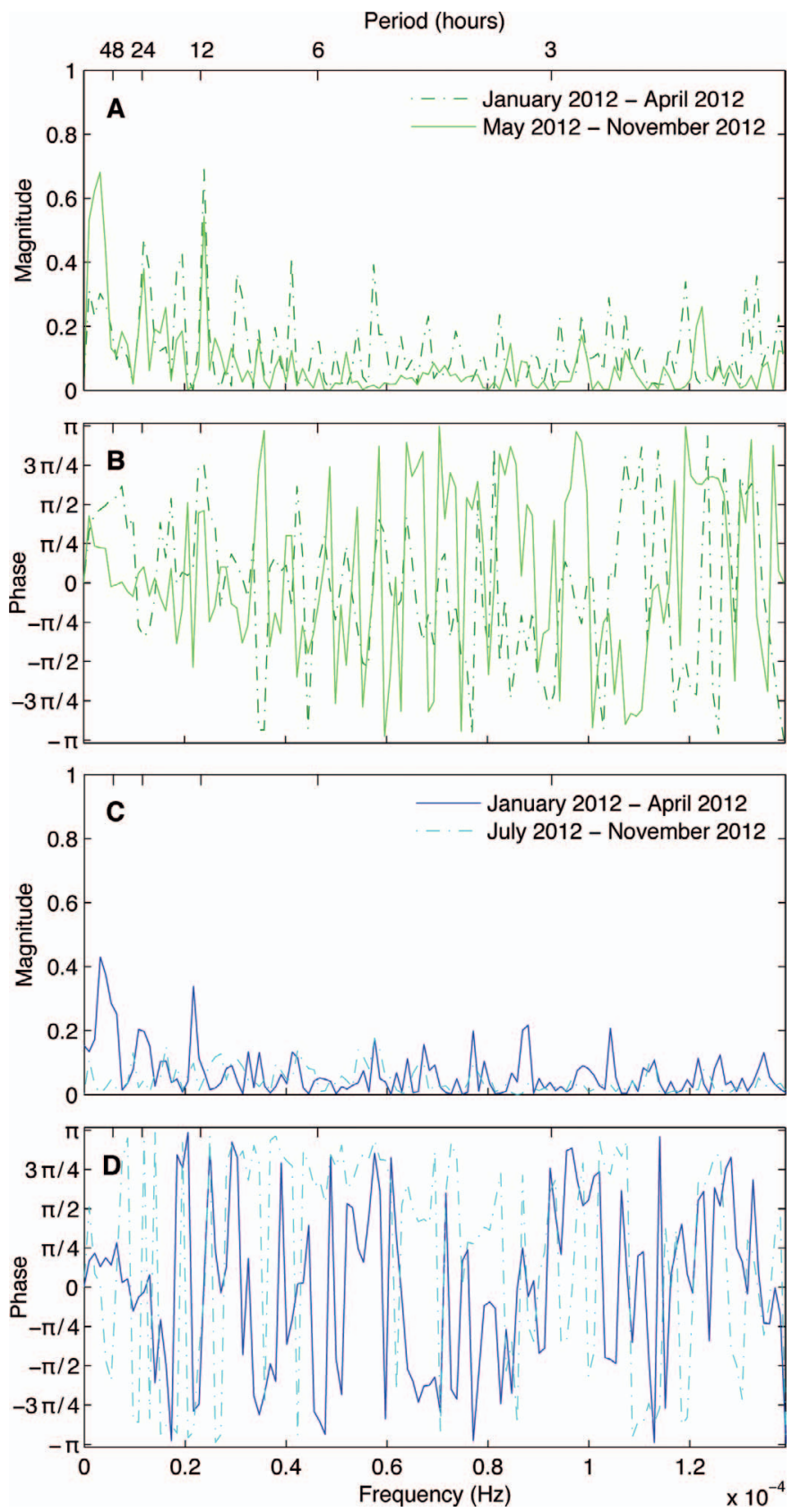

Figure 4. Cave water level $\mathrm{WL}_{\mathrm{C}}-p \mathrm{CO}_{2}$ coherency for Vallgornera and Drac (A and $C$ ) and the corresponding phase angles ( $B$ and $D)$. Top axis labels: time domain; bottom axis: frequency domain.

hypothesis. $\mathrm{p}-\mathrm{pCO}_{2}$ coherency was found throughout the year in both Vallgornera and Drac in approximately 12-hr cycles (Table 2). The different lead times do not support the potential relationship identified by $\mathrm{p}-\mathrm{pCO}_{2}$ coherency values, because $\mathrm{p}$ should exert a constant control irrespective of surface temperature and other variables. Further, the lack of replication of $\mathrm{p}-p \mathrm{CO}_{2}$ coherency values in Drac between the January - April 2012 data and the January - March 2013 


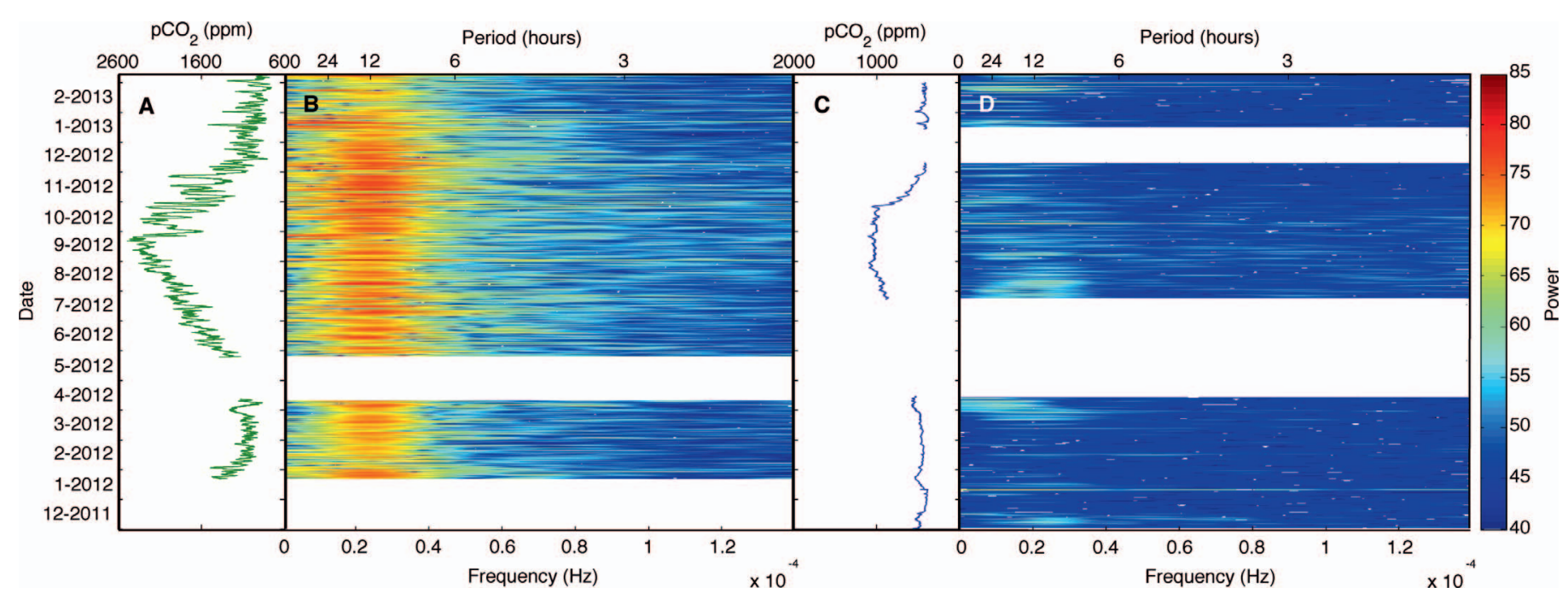

Figure 5. Vallgornera and Drac $p \mathrm{CO}_{2}$ time series (A and C) and their spectrograms (B and D).

series indicates that further work is necessary to evaluate the control of $\mathrm{p}$ on $p \mathrm{CO}_{2}$ fluctuations, at least in Drac. $\mathrm{p}-p \mathrm{CO}_{2}$ coherency values and consistent period and lead times in Vallgornera support the hypothesis that $p \mathrm{CO}_{2}$ responds to $\mathrm{p}$ in this near closed-system cave, but it is not the primary control.

Cave water level $\mathrm{WL}_{\mathrm{c}}-p \mathrm{CO}_{2}$ coherency values support the hypothesis that $\mathrm{WL}_{\mathrm{c}}$ affects $p \mathrm{CO}_{2}$ throughout the year in Vallgornera and to a lesser extent during the summer months in Drac (Fig. 4A and C, Table 2). This is reinforced by the spectral power observed at approximately $12 \mathrm{hr}$ in Vallgornera (Fig. 5B). These observations suggest that the transition from low- to high-water level forces higher- $p \mathrm{CO}_{2}$ air from the cave (Fig. 8A). Regardless of surface temperature, as the water recedes, tropospheric air sinks into the cave, with a volume equivalent to the volume reduction of seawater in the cave (a function of water level $\mathrm{WL}_{\mathrm{c}}$ ) (Fig. 8B). Significant cave temperature variation was not observed at either study site; any external thermal signal is attenuated.

In Vallgornera, a forward and reverse piston effect seems to dominate semidiurnal cave air exchange through the overlying bedrock, which is less than $20 \mathrm{~m}$ thick (Fig. 8). Twice-daily $p \mathrm{CO}_{2}$ variations on the order of $300 \mathrm{ppm}$ were recorded throughout the year. It is possible that in Vallgornera's extensive horizontal network of passages with limited vertical extent, the sensor recorded the movement of a boundary layer of $\mathrm{CO}_{2}$ maintained by degassing from the water (Badino, 2009), though no data are currently available to support or refute the presence of such a boundary layer at this site.

Exchange through the entrance likely dominates in Drac (Fig. 8). In addition to maintaining lower $p \mathrm{CO}_{2}$, Drac's large passages and few constrictions allow for cave water level driven exchange through its large entrance, which explains the lower amplitude of semidiurnal fluctuations that are only recorded during the summer months, when large-scale temperature-driven ventilation is inactive. Compared to Vallgornera, the Drac study room has greater volume, thus the amplitude of recorded $p \mathrm{CO}_{2}$ fluctuations may be much smaller due to the homogenous cave atmosphere maintained by temperature- and density-driven convection currents. More in-depth spatial (horizontal and vertical) $p \mathrm{CO}_{2}$ sampling is necessary to better constrain the dynamics of cave troposphere $p \mathrm{CO}_{2}$ exchange in both caves.

$\mathrm{CO}_{2}$ degassing from the cave water is an essential process for the formation of phreatic overgrowths on speleothems (Pomar et al., 1976, 1979; Csoma et al., 2006) and is driven by the gradient between $p \mathrm{CO}_{2}$ in the cave water and air (Boop et al., 2014). The lower overall $p \mathrm{CO}_{2}$ in Drac allows for periods of degassing that cause water to become supersaturated with respect to calcium carbonate, as evidenced by ephemeral rafts of calcite observed throughout the year. Conversely, relatively high $p \mathrm{CO}_{2}$ in Vallgornera is not presently conducive to extended periods of rapid $\mathrm{CO}_{2}$ exsolution. Thus, the conditions for supersaturation with respect to carbonate minerals and subsequent precipitation of POS are not currently satisfied (Boop et al., 2014). Based on the U/Th dates from a Vallgornera POS sample, these unfavorable geochemical conditions may have started 600 years ago (Tuccimei et al., 2009, 2010).

\section{CAVE WATER LEVEL}

The attenuation of the tide gauge water level $\mathrm{WL}_{\mathrm{P}}$ inside the littoral caves and the strong relationship between variation in it and the cave level $\mathrm{WL}_{\mathrm{c}}$, illustrated by very high coherency and robust linear correlations, further confirm that POS are excellent recorders of mean sea-level position.

Though $\mathrm{WL}_{\mathrm{c}}$ fluctuates with a roughly 4-hr lag behind $\mathrm{WL}_{\mathrm{P}}$, there is limited evidence of direct Mediterranean Sea water intrusion during this tidally-driven process (Boop et al., 2014). Cave water temperatures $T_{w}$ fluctuated less than $1{ }^{\circ} \mathrm{C}$ 
Interactions between surface conditions, the Mediterranean Sea, and cave climate within two littoral caves in Mallorca: IMPLICATIONS FOR THE FORMATION OF PHREATIC OVERGROWTHS ON SPELEOTHEMS
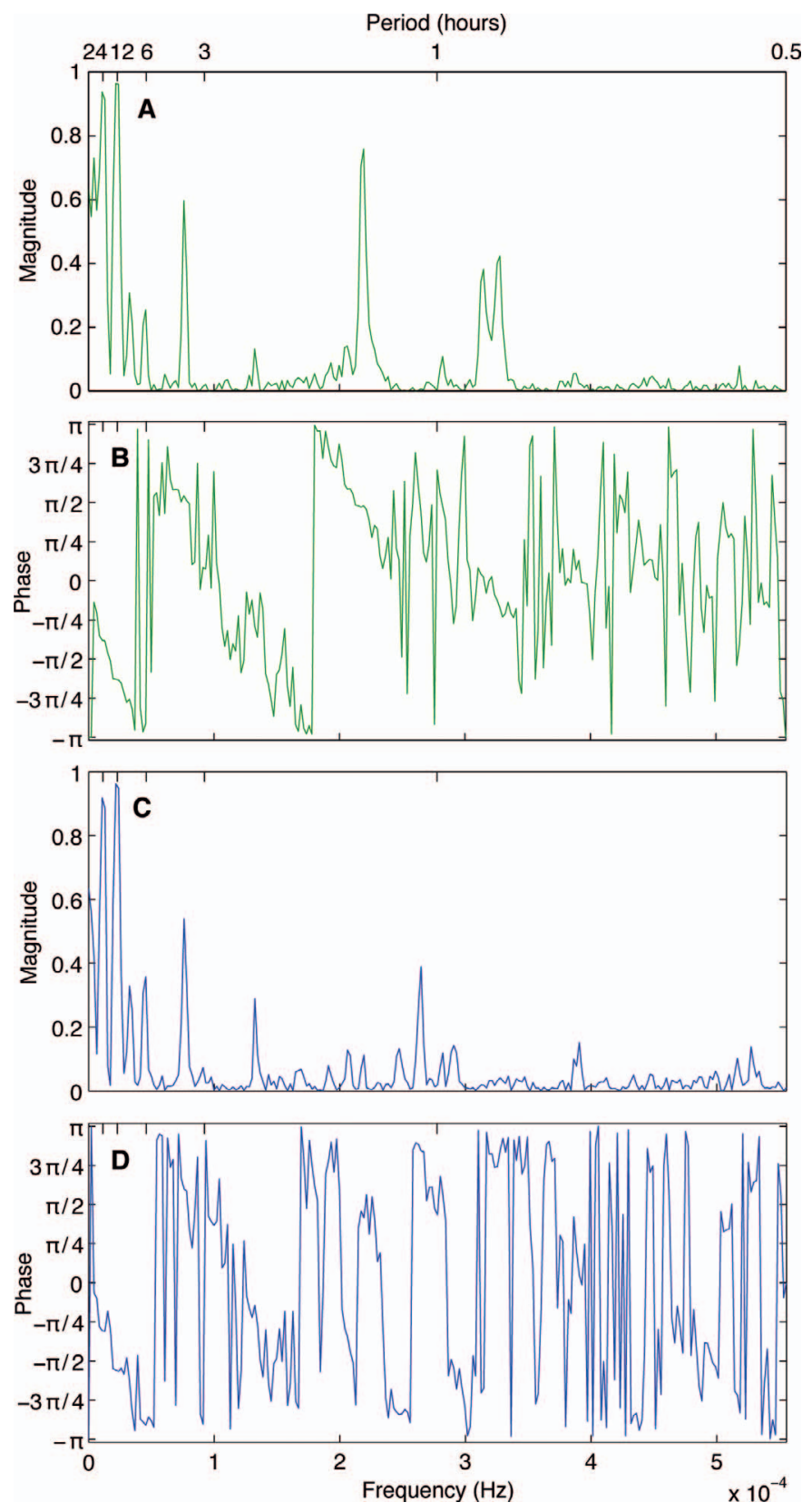

Figure 6. Vallgornera tide gauge level $\mathrm{WL}_{\mathrm{p}}$ - cave water level $W_{C}$ coherency $(A)$ and corresponding phase angles (B); same analyses for Drac (C and D). Top axis: time domain; bottom axis: frequency domain.

over the study period, with a higher range observed at Vallgornera than in Drac. Direct mixing with the Mediterranean Sea would introduce a strong annual period in $T_{w}$ because of changes in seawater temperature. Lack of mixing is further supported by the low turbidity of the water, lack of observed currents, and the maintenance of brackish water at the surface of both study sites (Boop et al., 2014). The latter condition is likely maintained throughout the year by meteoric recharge.

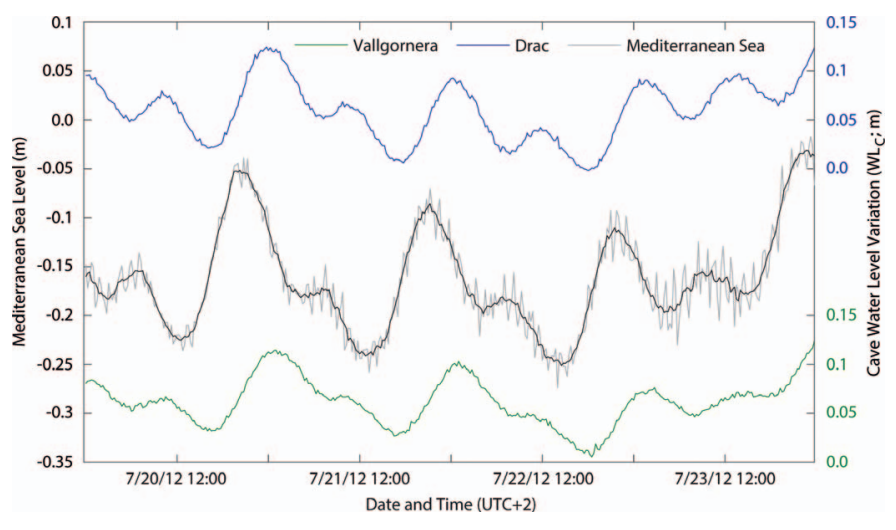

Figure 7. Expanded-scale cave water level $\left(W L_{C}\right)$ variation from July 20-23, 2012, and Mediterranean Sea level $\left(W L_{p}\right)$ (black line: 5-point moving average).

Time series analysis did not reveal a relationship between cave water levels and precipitation. In non-coastal areas, time series analysis can identify the effect of rainfall on karst aquifers (Padilla \& Pulido-Bosch, 1995; Larocque et al., 1998; Panagopoulos \& Lambrakis, 2006; Bailly-Comte et al., 2008). However, analyses based on spring discharge or piezometric head are not applicable to understand controls on water level in Mallorca's littoral caves because water level is dominantly controlled by the Mediterranean Sea level. Similarly, Kim et al. (2005) were unable to identify any effect of precipitation on coastal water levels in Korea and attribute fluctuations solely to the tidal effect using time series analysis.

\section{Conclusions}

The phreatic overgrowths on speleothems found in the littoral caves of Mallorca are valuable paleo-sea level index points. These encrustations form at the cave water table, which is, and was in the past, coincident with sea level because of the negligible hydraulic gradient between the caves and the Mediterranean Sea. The present study validates the assumption that the cave water levels fluctuate in response to the Mediterranean Sea tide by identifying an approximately 4$\mathrm{hr}$ lag of $\mathrm{WL}_{\mathrm{c}}$ behind the tide gauge level in the sea $\mathrm{WL}_{\mathrm{P}}$. The semidiurnal signal is preserved, though slightly attenuated, in $\mathrm{WL}_{\mathrm{c}}$ at each study site. The primary control of $\mathrm{WL}_{\mathrm{P}}$ masks any direct effect of $\mathrm{P}$ on $\mathrm{WL}_{\mathrm{c}}$.

The present study, Boop (2014), and Boop et al. (2014) monitored conditions relevant to the precipitation of phreatic overgrowths on speleothems. Some caves may be more likely to host the specific geochemical conditions necessary for their precipitation. These conditions are met when cave water is supersaturated with respect to carbonate minerals at times when $\mathrm{CO}_{2}$ degasses from water into the cave atmosphere. A high concentration gradient between $p \mathrm{CO}_{2}$ of the water and air promotes this process. Thus, faster degassing, and therefore 

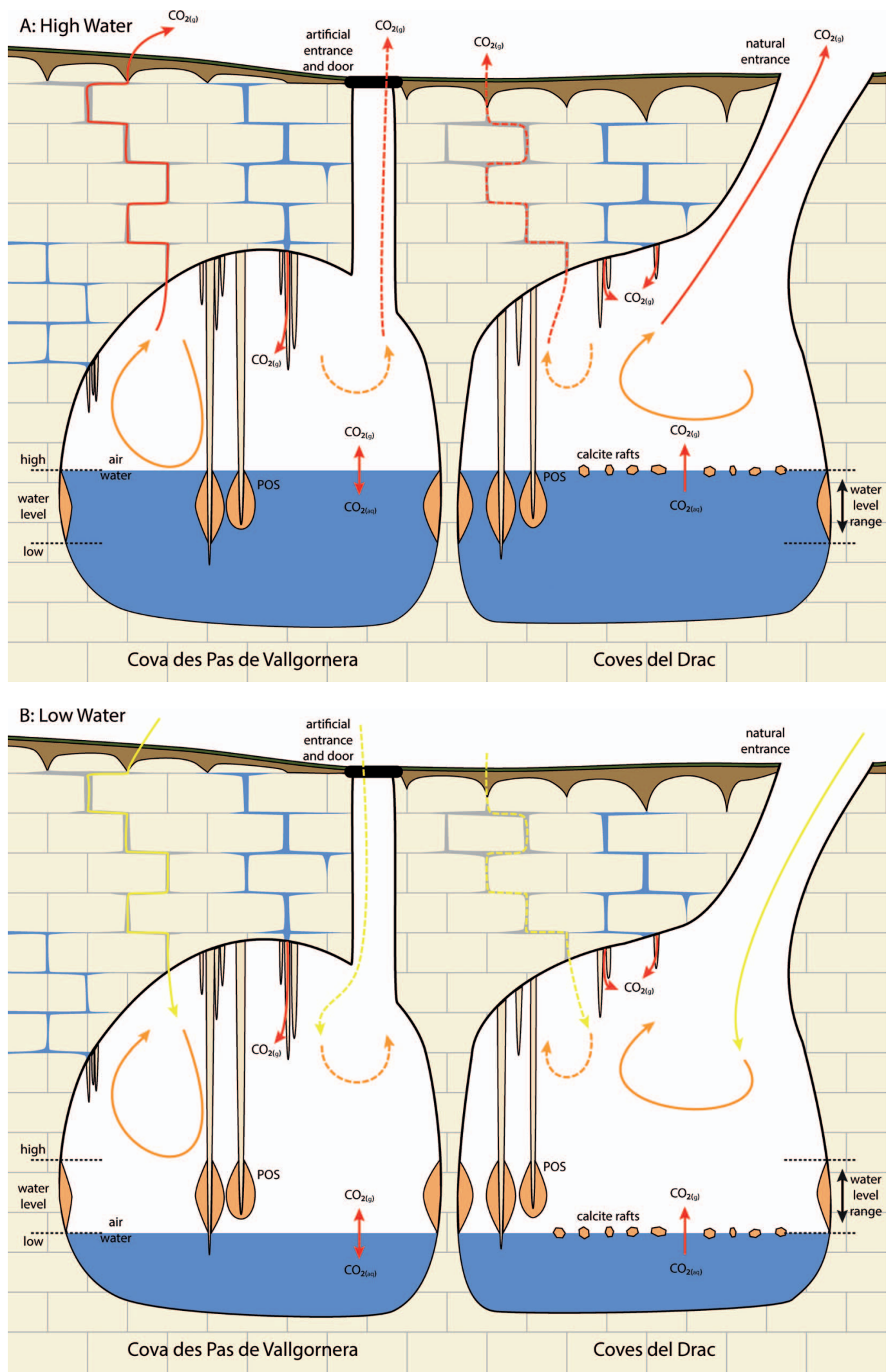

Figure 8. A simplified model of semidiurnal $\mathrm{pCO}_{2}$ dynamics in Vallgornera (left) and Drac (right) associated with the rising (A) or receding (B) of the cave water level, which is overprinted on seasonal (winter) ventilation. Phreatic overgrowths on speleothems appear to be actively growing today in Drac but not in Vallgornera. See text for additional explanations. 
Interactions between surface conditions, the Mediterranean Sea, and cave climate within two littoral caves in Mallorca: IMPLICATIONS FOR THE FORMATION OF PHREATIC OVERGROWTHS ON SPELEOTHEMS

solution supersaturation and possible precipitation of POS, is expected to occur with low cave air $\mathrm{CCO}_{2}$. The annual cycle in $p \mathrm{CO}_{2}$ is driven by cave ventilation in the winter months, when colder, denser tropospheric air sinks through the bedrock or entrances into subsurface voids, displacing cave air and reducing $p \mathrm{CO}_{2}$. The thermal signature of this tropospheric air is quickly attenuated within the caves; cave air and cave water temperatures vary by less than $1{ }^{\circ} \mathrm{C}$ throughout the year and lag behind surface temperature by several months. $p \mathrm{CO}_{2}$ fluctuations have larger amplitudes in Vallgornera, likely due to the overall higher $p \mathrm{CO}_{2}$ and the constricted nature of the study site. It is likely that at both sites, rising cave water level due to barometric pressure changes and tidal pumping (Fig. $8 \mathrm{~A}$ ) forces high $p \mathrm{CO}_{2}$ air out from the cave, driving semidiurnal tropospheric exchange throughout the year with a roughly 12-hr period. In Vallgornera, air escapes dominantly through the bedrock fissures (solid red line in Fig. 8A), whereas Drac's less-constricted passages promote displacement through its large natural entrance. When $\mathrm{WL}_{\mathrm{c}}$ recedes (Fig. 8B), tropospheric air sinks into the cave through the bedrock in Vallgornera (solid yellow line) and primarily through the entrance in Drac. Vallgornera's nearly sealed entrance, maze-like passages, and constrictions promote the buildup of higher concentrations of $\mathrm{pCO}_{2}$ throughout the year, restricting $\mathrm{CO}_{2}$ degassing from the water, thus suppressing calcium carbonate supersaturation and POS precipitation. In Drac, $p \mathrm{CO}_{2}$ is lower throughout the year, which maintains conditions for $\mathrm{CO}_{2}$ to degas from the cave water to air; this promotes calcium carbonate supersaturation, and thus, precipitation of ephemeral rafts and POS.

\section{ACKNOWLEDGMENTS}

This material is based upon work supported by the National Science Foundation under grant AGS-1103108 to BPO and MINECO projects CGL2013-48441-P and CGL2016-79246-P (AEI/FEDER, UE) to JJF. LMB received student research grants from the National Speleological Society and the Geological Society of America. AEMet is thanked for providing the temperature and precipitation records for Llucmajor II and Manacor-Poliesportiu that were used in this study. Scott McBride (USGS Tampa) is thanked for lending two YSI 6920 sensors for this study, as well as his invaluable guidance. We are grateful to Tony Merino, Marta RodríguezHomar, Joaquín Ginés, and Angel Ginés for their dedication in the field. We are indebted to the administration of Coves del Drac (Porto Cristo) for granting permission to perform research in the cave. We additionally appreciate the Federació Balear d'Espeleologia and the Department de Cultura i Patrimoni del Consell de Mallorca, as well as the Direcció General de d'Espais Naturals i Biodiversitat del Govern de les Illes Balears for helping with legal permissions for our work in Vallgornera. This paper benefited from discussions at the NSF- and PAGES-sponsored workshop on Sea-level changes into MIS 5: from observation to prediction (award AGS-
1032243 to BPO). Finally, this manuscript was greatly improved through the thoughtful suggestions of three anonymous reviewers.

\section{REFERENCES}

Badino, G., 2009, The legend of carbon dioxide heaviness: Journal of Cave and Karst Studies, v. 71, no. 1, p. 100-107.

Bailly-Comte, V., Jourde, H., Roesch, A., Pistre, S., and Batiot-Guihe, C., 2008, Time series analyses for karst/river interactions assessment: Case of the Coulazou river (southern France): Journal of Hydrology, v. 349, p. 98 114, https://doi.org/10.1016/j.jhydrol.2007.10.028.

Baldini, J.U.L., Baldini, L.M., McDermott, F., and Clipson, N., 2006, Carbon dioxide sources, sinks, and spatial variability in shallow temperate zone caves: evidence from Ballynamintra Cave, Ireland: Journal of Cave and Karst Studies, v. 68, p. 4-11.

Banner, J.L., Guilfoyle, A., James, E.W., Stern, L.A., and Musgrove, M., 2007, Seasonal variations in modern speleothem calcite growth in central Texas, U.S.A.: Journal of Sedimentary Research, v. 77, p. 615-622, https://doi.org/10.2110/jsr.2007.065.

Benavente, J., Vadillo, I., Liñan, C., Carrasco, F., and Soler, A., 2011, Ventilation effects in a karstic show cave and in its vadose environment, Nerja, Southern Spain: Carbonates and Evaporites, v. 26, 11-17, https:// doi.org/10.1007/s13146-011-0050-9.

Boop, L.M., 2014, Characterization of the Depositional Environment of Phreatic Overgrowths on Speleothems in the Littoral Caves of Mallorca (Spain): a Physical, Geochemical, and Stable Isotopic Study [Ph.D. thesis]: Tampa, University of South Florida, 128 p.

Boop, L.M., Onac, B.P., Wynn, J.G., Fornós, J.J., Rodríguez-Homar, M., and Merino, A., 2014, Groundwater geochemistry observations in littoral caves of Mallorca (western Mediterranean): implications for deposition of phreatic overgrowths on speleothems: International Journal of Speleology, v. 43, no. 2, p. 193-203, https://doi.org/10.5038/1827-806X.43.2.7.

Butzer, K.W., 1962, Coastal geomorphology of Majorca: Annals of the Association of American Geographers, v. 52, no. 2, p. 191-212, https:// doi.org/10.1111/j.1467-8306.1962.tb00405.x.

Butzer, K.W., and Cuerda, J., 1962, Coastal stratigraphy of southern Mallorca and its implications for Pleistocene chronology of the Mediterranean Sea: Journal of Geology, v. 70, p. 389-416, https://doi.org/10.1086/626833.

Cowan, B.D., Osborne, M.C., and Banner, J.L., 2013, Temporal variability of cave-air $\mathrm{CO}_{2}$ in central Texas: Journal of Cave and Karst Studies, v. 75, no. 1, p. 38-50, https://doi.org/10.4311/2011ES0246.

Csoma, A.E., Goldstein, R.H., and Pomar, L., 2006, Pleistocene speleothems of Mallorca; implications for paleoclimate and carbonate diagenesis in mixing zones: Sedimentology, v. 53, p. 213-236, https://doi.org/10.1111/j. 1365-3091.2005.00759.x.

Cuerda, J., 1975, Los tiempos cuaternarios en Baleares: Palma de Mallorca, Instituto de Estudios Baleáricos, $304 \mathrm{p}$

Dorale, J.A., Onac, B.P., Fornós, J.J., Ginés, J., Ginés, A., Tuccimei, P., and Peate, D.W., 2010, Sea-level highstand 81,000 years ago in Mallorca: Science, v. 327 , no. 5967 , p. $860-863$, https://doi.org/10.1126/science. 1181725 .

Dumitru, O.A., Onac, B.P., Fornós, J.J., Cosma, C., Ginés, A., Ginés, J., and Merino, A., 2015, Radon survey in caves from Mallorca Island, Spain: Science of Total Environment, v. 526, p. 196-203, https://doi.org/10.1016/ j.scitotenv.2015.04.076.

Ek, C., and Gewelt, M., 1985, Carbon dioxide in cave atmospheres. New results in Belgium and comparison with some other countries: Earth Surface Processes and Landforms, v. 10, p. 173-187, https://doi.org/10. 1002/esp.3290100209.

Faimon, J., Ličbinská, M., Zajíček, P., and Sracek, O., 2012, Partial pressures of $\mathrm{CO}_{2}$ in epikarstic zone deduced from hydrogeochemistry of permanent drips, the Moravian karst, Czech Republic: Acta Carsologica, v. 41, no. 1, p. $47-57$.

Fornós, J.J., Gelabert, B., Ginés, A., Ginés, J., Tuccimei, P., and Vesica, P., 2002, Phreatic overgrowths on speleothems: a useful tool in structural geology in littoral karstic landscapes. The example of eastern Mallorca (Balearic Islands): Geodinamica Acta, v. 15, p. 113-125, https://doi.org/ 10.1080/09853111.2002.10510745.

Fornós, J.J., Merino, A., Ginés, J., Ginés, A., and Gràcia, A., 2011, Solutional features and cave deposits related to hypogene speleogenetic processes in 
a littoral cave of Mallorca Island (western Mediterranean): Carbonates and Evaporites, v. 26, p. 69-81, https://doi.org/10.1007/s13146-010-0040-3.

García M.-J., Pérez, B., Fraile, M.-A., and Millan, J.G., 2000, Sea level variability along the Spanish Coast, 1990-1999. 10 ${ }^{\text {th }}$ General Assembly WEGENER Project, Extended Abstract Book, San Fernando. Boletín no 3/ 200 del Real Observatorio de la Armada, San Fernando, España, 5 p.

Ginés, J., 2000, El karst litoral en el levante de Mallorca: una aproximación al conocimiento de sus morfogénesis y cronología [Ph.D. thesis]: Palma de Mallorca, Universitat de les Illes Balears, 595 p.

Ginés, J., Fornós, J.J., Ginés, A., Merino, A., and Gràcia, F., 2014, Geologic constraints and speleogenesis of Cova des Pas de Vallgornera, a complex coastal cave from Mallorca Island (Western Mediterranean): International Journal of Speleology, v. 43, no. 2, 105-124, https://doi.org/10.5038/ 1827-806X.43.2.2.

Ginés, A., and Ginés, J., 1972, Consideraciones sobre los mecanismos de fosilización de la Cova de Sa Bassa Blanca y su paralelismo con las formaciones marinas del Cuaternario, in Proceedings, II Congreso Nacional de Espeleología, Oviedo, Spain, p. 11-28.

Ginés, A., and Ginés, J., 2007, Eogenetic karst, glacioeustatic cave pools and anchialine environments on Mallorca Island: a discussion of coastal speleogenesis: International Journal of Speleology, v. 36, no. 2, p. 57-67, https://doi.org/10.5038/1827-806X.36.2.1.

Ginés, A., Ginés, J., Fornós, J.J., Bover, P., Gómez-Pujol, L., Gràcia, F., Merino, A., and Vicens, D., 2012a, An introduction to the Quaternary of Mallorca, in Ginés, A., Ginés, J., Gómez-Pujol, L., Onac, B.P., and Fornós, J.J., eds., Mallorca: A Mediterranean Benchmark for Quaternary Studies: Monografies de la Societat d'Història Natural de les Balears, v. 18, p. 1353.

Ginés, J., Ginés, A., Fornós, J.J., Merino, A., and Gràcia, F., 2009, About the genesis of an exceptional coastal cave from Mallorca Island (western Mediterranean); the lithological control over the pattern and morphology of Cova des Pas de Vallgornera, in White, W.B., ed., Proceedings of the $15^{\text {th }}$ International Congress of Speleology: Kerrville, Texas, v. 1, p. $481-$ 487.

Ginés, J., Ginés, A., Fornós, J.J., Tuccimei, P., Onac, B.P., and Gràcia, F., 2012b, Phreatic overgrowths on speleothems (POS) from Mallorca, Spain: updating forty years of research, in Ginés, A., Ginés, J., Gómez-Pujol, L., Onac, B.P., and Fornós, J.J., eds., Mallorca: A Mediterranean Benchmark for Quaternary Studies: Monografies de la Societat d'Història Natural de les Balears, v. 18, p. 111-146.

González-Hernández, F.M., Goy, J.L., Zazo, C., and Silva, P.G., 2001, Actividad eolica — cambios del nivel del mar durante los últimos 170,000 anos (litoral de Mallorca, Islas Baleares): Cuaternario y Geomorfologia, v. 15 , no. $3-4$, p. $67-75$

Goy, J.L., and Zazo, C., 1986, Synthesis of the quaternary in the Almeria littoral neotectonic activity and its morphologic features, Western Betics, Spain: Tectonophysics, v. 130 , no. 1-4, p. 259-270, https://doi.org/10. 1016/0040-1951(86)90116-2.

Gràcia, F., Fornós, J.J., and Clamor, B., 2007, Cavitats costaneres de les Balears generades a la zona de mescal, amb importants continuacions subaquàtiques, in Pons, G.X., and Vicens, D., eds., Geomorfologia litoral i Quaternari, Homenatge a Joan Cuerda Barceló, Monografies de la Societat d'Història Natural de les Balears, v. 14, p. 299-352.

Guijarro, J.A., 1995, Bioclimatic aspects of karst in Mallorca: Endins, v. 20, p. $17-26$.

Hearty, P.J., 1987, New data on the Pleistocene of Mallorca: Quaternary Science Reviews, v. 6, p. 245-257, https://doi.org/10.1016/ 0277-3791(87)90007-2

Hearty, P.J., Miller, G.H., Stearns, C.E., and Szabo, B.J., 1986, Aminostratigraphy of Quaternary shorelines in the Mediterranean basin: Geological Society of America Bulletin, v. 97, no. 7, p. 850-858, https://doi.org/10.1130/0016-7606(1986)97<850:AOQSIT>2.0.CO;2.

Just, J., Hübscher, C., Betzler, C., Lüdmann, T., and Reicherter, K., 2011, Erosion of continental Mediterranean due to sea-level stagnancy during the Messinian Salinity Crisis: Geo-Marine Letters, v. 31, p. 51-64. https:// doi.org/10.1007/s00367-010-0213-z.

$\mathrm{Hu}$, Chaoyong, Henderson, G.M., Huang, Junhua, Chen, Zhenhong, and Johnson, K.R., 2008, Report of a three-year monitoring programme at Heshang Cave, Central China: International Journal of Speleology, v. 37, no. 3, p. 143-151. https://doi.org/10.5038/1827-806X.37.3.1.

Kim, JJi-Hoon, Lee, Jeongho, Cheong, Tae-Jin, Kim, Rak-Hyeon, Koh, DongChen, Ryu, Joh-Sik, and Chang, Ho-Wan, 2005, Use of time series analysis for the identification of tidal effect on groundwater in the coastal area of Kimje, Korea: Journal of Hydrology, v. 300, p. 188-198, https:// doi.org/10.1016/j.jhydrol.2004.06.004

Lang, M., Faimon, J., Godissart, J., and Ek, C., 2016, Carbon dioxide seasonality in dynamically ventilated caves: the role of advective fluxes: Theoretical and Applied Climatology, https://doi.org/10.1007/ s00704-016-1858-y.

Larocque, M., Mangin, A., Razack, M., and Banton, O., 1998, Contribution of correlation and spectral analyses to the regional study of a large karst aquifer (Charente, France): Journal of Hydrology, v. 205, p. 217-231, https://doi.org/10.1016/S0022-1694(97)00155-8.

Liñán, C., Vadillo, I., and Carrasco, F., 2008, Carbon dioxide concentration in air within the Nerja Cave (Malaga, Andalusia, Spain): International Journal of Speleology, v. 37, no. 2, p. 99-106, https://doi.org/10.5038/ 1827-806X.37.2.2.

López-García, J.M., and Mateos-Ruíz, R.M., 2006, Control estructural de las anomalías geotérmicas y la intrusión marina en la platforma de Llucmajor y La Cubeta de Campos (Mallorca), in Las Aguas Subterráneas en los Paises Mediterráneos: Madrid, Instituto Geológico y Minero de España, series Hidrogeología y Aguas Subterráneas 17, p. 607-613.

Mandić, M., Mihevc, A., Leis, A., and Bronić, I.K., 2013, Concentration and stable carbon isotopic composition of $\mathrm{CO}_{2}$ in cave air of Postojnksa jama, Slovenia: International Journal of Speleology, v. 42, no. 3, p. 279-287, https://doi.org/10.5038/1827-806X.42.3.11.

Merino, A., 1993, La Cova des Pas de Vallgornera (Llucmajor, Mallorca): Endins, v. 19, p. 17-23.

Merino, A., Mulet, A., Mulet, G., Croix, A., Kristofersson, A., Gràcia, F., Ginés, J., and Fornós, J.J., 2011, La Cova des Pas de Vallgornera (Llucmajor, Mallorca). La cavitat de major desenvolupament de les Illes Balears: Endins, v. 35, p. 147-164.

Merino, A., Mulet, A., Mulet, G., Croix, A., Kristofersson, A., Gràcia, F., and Perelló, M.A., 2014, Cova des Pas de Vallgornera (Mallorca, Spain): history of exploration and cave description: International Journal of Speleology, v. 43, no. 2, p. 95-104, https://doi.org/10.5038/1827-806X.43. 2.1 .

Onac, B.P., Fornós, J.J., Merino, A., Ginés, J., and Diehl, J., 2014, Linking mineral deposits to speleogenetic processes in Cova des Pas de Vallgornera (Mallorca, Spain): International Journal of Speleology, v. 43, no. 2, 143-157, https://doi.org/10.5038/1827-806X.43.2.4.

Padilla, A., and Pulido-Bosch, A., 1995, Study of hydrographs of karstic aquifers by means of correlation and cross-spectral analysis: Journal of Hydrology, v. 168, p. 73-89, https://doi.org/10.1016/ 0022-1694(94)02648-U.

Panagopoulos, G., and Lambrakis, N., 2006, The contribution of time series analysis to the study of the hydrodynamic characteristics of the karst systems: Application on two typical karst aquifers of Greece (Trifilia, Almyros Crete): Journal of Hydrology, v. 329, p. 368-376, https://doi.org/ 10.1016/j.jhydrol.2006.02.023.

Pomar, L., and Cuerda, J., 1979, Los depósitos marinos pleistocénicos en Mallorca: Acta Geológica Hispánica, v. 14, p. 505-513.

Pomar, L., Ginés, A., and Fontarnau, R., 1976, Las cristalizaciones freaticas: Endins, v. 3, p. 3-25.

Pomar, L., Ginés, A., and Ginés, J., 1979, Morfología, estructura y origen de los espeleotemas epiacuáticos: Endins, v. 5-6, p. 3-17.

Robledo, P.A., and Durán, J.J., 2010, Evolución del turismo subterráneo en las Islas Baleares y su papel en el modelo turístico, in Durán, J.J., and Carrasco, F., eds., Cuevas: Madrid, España Asociación de Cuevas Turísticas Españolas, patrimonio, naturaleza, cultura y turismo, p. 305323.

Sàbat, F., Gelabert, B., Rodríguez-Perea, A., and Giménez, J., 2011, Geological structure and evolution of Mallorca: Implications for the origin of the Western Mediterranean: Tectonophysics, v. 510, p. 217-238. https://doi.org/10.1016/j.tecto.2011.07.005.

Spötl, C., Fairchild, I.J., and Tooth, A.F., 2005, Cave air control on dripwater geochemistry, Obir Caves (Austria): Implications for speleothem deposition in dynamically ventilated caves: Geochimica et Cosmochimica Acta, v. 69 , no. 10 , p. 2451-2468, https://doi.org/10.1016/j.gca.2004.12.009.

Tuccimei, P., Ginés, J., Delitala, M.C., Ginés, A., Gràcia, F., Fornós, J.J., and Taddeucci, A., 2006, Last interglacial sea level changes in Mallorca Island (Western Mediterranean); high precision U-series data from phreatic overgrowths on speleothems: Zeitschrift für Geomorphologie, v. 50, no. 1, p. 1-21. https://doi.org/10.1127/zfg/50/2006/1.

Tuccimei, P., Soligo, M., Fornós, J.J., Ginés, A., Ginés, J., Onac, B.P., and Villa, I.M., 2009, Precipitation of phreatic overgrowths at the water table of meteoric-marine mixing zones in coastal cave systems; a useful tool in 
Interactions between surface conditions, the Mediterranean Sea, and cave climate within two littoral caves in Mallorca: IMPLICATIONS FOR THE FORMATION OF PHREATIC OVERGROWTHS ON SPELEOTHEMS

sea-level change reconstruction, in White, W.B., ed., Proceedings of the $15^{\text {th }}$ International Congress of Speleology: Kerrville, Texas, v. 1, p. 554 560.

Tuccimei, P., Soligo, M., Ginés, J., Ginés, A., Fornós, J.J., Kramers, J., and Villa, I.M., 2010, Constraining Holocene sea-levels using U/Th ages of phreatic overgrowths on speleothems from coastal caves in Mallorca (western Mediterranean): Earth Surface Processes and Landforms, v. 35, no. 7, p. 782-790, https://doi.org/10.1002/esp.1955.

UNESCO-IOC, sea-level data for Palma de Mallorca, www. ioc-sealevelmonitoring.org/station.php?code=palm [accessed: April 2016]

van Hengstum, P.J., Richards, D.A., Onac, B.P., Dorale, J.A., 2015, Coastal caves and sinkholes, in Shennan, I., Long, A.J., and Horton, B.P., eds.,
Handbook for Sea-Level Research, Oxford, John Wiley \& Sons, p. 83103, https://doi.org/10.1002/9781118452547.ch6.

Vesica, P.L., Tuccimei, P., Turi, B., Fornós, J.J., Ginés, A., and Ginés, J., 2000, Late Pleistocene paleoclimates and sea-level change in the Mediterranean as inferred from stable isotope and U-series studies of overgrowths on speleothems, Mallorca, Spain: Quaternary Science Reviews, v. 19, p. 865-879, https://doi.org/10.1016/ S0277-3791(99)00026-8.

Wigley, T.M.L., and Brown, M.C., 1976, The physics of caves, in Ford, D.T., and Cullingford, C.H.C., eds., The science of Speleology: London, Academic Press, p. 329-358. 